\section{Mirko Starčević}

University of Ljubljana

Faculty of Arts
2015, Vol. 12 (2), 129-145(244)

revije.ff.uni-lj.si/elope

doi: 10.4312/elope.12.2.129-145

UDC: 821.111.09-1Newman J. H.:273.4

\title{
John Henry Newman and the Oxford Movement: A Poet of the Church
}

\author{
ABSTRACT
}

The paper examines John Henry Newman and the extent to which his involvement with the Oxford Movement influenced his poetic endeavours. The analysis of the historical and theological background of the Movement from Newman's perspective makes the task of presenting the genesis of Newman's poetic conceptions much easier. Newman was famous for being a preternaturally gifted preacher and prose writer, while his poetic texts received less attention. The examination of poetry is carried out here by contrasting the Oxford Movement's ideas, majorly Newman's own ideas and poetry, with Romanticism as the high guardian of Imagination and furor poeticus. While the Romantic poets craved authenticity and defied the laws of imitative modes of expression, the devotional poets of that time oftentimes leaned on mimesis. The paper's objective, therefore, is to help define the prominence of imitative elements in Newman's poetry and their impact on the quality of his verse.

Keywords: Newman; the Oxford Movement; poetry; Romanticism; Via Media

\section{John Henry Newman in Oxfordsko gibanje: Pesnik cerkve}

\section{POVZETEK}

Članek obravnava Johna Henryja Newmana in vpliv, ki ga je imela njegova udeležba v Oxfordskem gibanju na njegovo lastno poetično udejstvovanje. Analiza zgodovinskega in teološkega ozadja Oxfordskega gibanja z Newmanovega gledišča je olajšala predstavitev zapletenosti njegovega pesniškega razvoja. Newman je bil poznan po nevsakdanji pridigarski in pisateljski nadarjenosti, a pesniška dela, ki jih je ustvaril, so bila navadno deležna precej manj pozornosti. Razmišljanja o poeziji so podana v obliki kontrastne analize idej Oxfordskega gibanja - in s tem Newmanovih lastnih idej in poezije - in romantike, domovanja varuha domišljije in pesniške blaznosti. Medtem ko so romantiki hrepeneli po avtentičnosti in se zoperstavljali zakonom posnemovalnih oblik izražanja, se je nabožna poezija navadno oslanjala na mimetičnost. Cilj članka torej lahko opredelimo kot poizkus določitve razsežnosti mimetičnih elementov prisotnih v Newmanovi poeziji in njihov vpliv na kvaliteto njegovega verza.

Ključne besede: Newman; Oxfordsko gibanje; poezija; romantika; Via Media 


\section{John Henry Newman and the Oxford Movement: A Poet of the Church}

\section{Introduction}

Oxford of the 19th century was a fertile source of both aesthetic and religious movements, out of which the Oxford Movement emerged as the one having the largest impact on all subsequent intellectual formations, be they theological or aesthetic, of the 19th century Oxford and Britain at large. The nucleus of the Movement was John Henry Newman, an Anglican preacher and later a convert to the Roman Catholic Church.

One of the aims of this paper is to present the historical and theological background of Newman's involvement with the Movement, for only upon the basis of a thorough analysis of Newman's ideological association with the Oxford Movement can the second and main aim - a re-evaluation of Newman's poetic endeavours - be satisfactorily attained.

In James Joyce's The Portrait of the Artist as a Young Man, Vincent Heron made a slightly caustic retort to Stephen Dedalus' proclamation of Newman as the greatest prose master in English: "O, many say that Newman has the best prose style ... of course he's not a poet" $(2000,85)$. Heron's observation of Newman as the best prose stylist may be a bit flippant, for the philosophical nature and intricacies of Newman's prose far exceed the ingredients of merely a great prose stylist; the latter part of his comment, however, due to Newman's rather dubious ventures into the province of poetry, demands more attention. The second objective of the paper is, therefore, twofold: (1) to juxtapose Newman's poetry and theory of poetry with his religious views, and determine the extent of influence these views exerted upon his verse; (2) to contrast Newman's poetic work with Romantic poetry (particularly with Coleridge) as a quintessential example of poetic creation as poiesis as opposed to mimesis, and in this manner define Newman's relationship to poetry as a force of creation rather than imitation.

\section{The Historical and Theological Background of The Oxford Movement}

In the small village of Littlemore, John Henry Newman, on September 25, 1843, read his very last sermon as an Anglican preacher. His had long been a tempestuous existence which saw its peak amidst the political and theological vicissitudes of the budding Victorian days. Newman's letter of resignation delivered a month before to the Lord Bishop of Oxford, Richard Bagot, promised not only a departure from the cherished banks of Littlemore Church and its parishioners; it was most of all a grief-stricken parting of friends. Edward Bouverie Pusey was among many of Newman's friends present at the sermon where the overarching proximity of Newman's retirement from the Anglican pulpit left him not secluded from the regnant wave of dolefulness. The events precipitating Newman's decision to leave the vicarage of The University Church of St. Mary, whose jurisdiction extended to Littlemore, deserve proper perspective.

On July 14, 1833, John Keble delivered the Assize Sermon in the University Church of Oxford, which in most historians' minds marks the official commencement of the Oxford movement. Opinions, however, differ as to the exact date of the Movement's formation, and, as George Herring points out, a plausible surmise exists that the Movement's ideological seeds might have first been planted in the 1820s (Herring 2002, 4). Some of its prominent members were John 
Keble, Richard Hurrell Froude, Edward Bouverie Pusey, while John Henry Newman loomed as an especially luminary figure.

So profound were Newman's role and influence within the Movement that many historians and theologians regard his conversion - when in 1845 Father Dominic Barberi received Newman into the Roman Catholic Church - and his subsequent exit as representing the dissolution of the Movement, but this can easily be disproved. First, many in the Movement, either due to their intrinsically more Evangelical or High Church leanings, did not share in Newman's penchant for all matters Roman, so out of a sinking ship they built a foundation that was much more in keeping with their own views; and second, most had never even heard Newman preach, and a substantial number of devotees had joined the Movement either through personal contact with some of its leading members or as a result of reading the Tracts which served as the primary means of the movement's dissemination of their never fully undivided ideas (Herring 2002, 65-68).

Tracts for the Times was a series of ninety Tracts, most of them published anonymously - although their authorship was more often than not easily inferred from the ideas promulgated in the Tracts - whose existence arched over an eight-year period (1833-1841). It was for this reason that the Oxford Movement came to be referred to as the Tractarian Movement, or, simply, The Tractarians. It is impossible to fully comprehend the basic tenets of the Tractarians without first taking into consideration societal changes that took place in the late 1820s. This was a time emblazoned with political reform. The Tories' already crumbling political structure further debilitated owing to Robert Peel's dwindling approach to the issue of Catholic Emancipation. Newman himself, after Peel had elected to endorse the motion, expressed his opposition to "the re-election of the Home Secretary Robert Peel as a member of parliament for the University of Oxford" (Gilley 2009, 5). The Church's autonomy was fragmenting, and the widespread fears of the Erastian doctrine of the National Church can best be illustrated with a short passage from Richard Hurrell Froude's posthumously published work Remains:

The true cause of the decay of Church Discipline is not that nations have become Christian, but that the clergy wished them to appear Christian, either before they were so after they have ceased to be so ... The body of the English nation either are sincere Christians or they are not: if they are, they will submit to Discipline as readily as the primitive Christians did. If not, let us tell the truth and shame the devil: let us give up a national Church and have a real one. (1839, 273-74).

The anguish of the clergy inspired by the mounting surge of Erastianism finally matured with the repeal of the Test and Corporations Acts, henceforth unburdening the government officials from the stipulation obligating them to partake of communion in the Church of England. The most overwhelming of horrors for the Anglican community, especially the non-liberal sector, came to pass: government positions would from that time on be occupied by Catholics or Dissenters also. Some of the High Anglican faithful desired to have their Church stand impervious to the webwork of political dogmatism and demagogy, yet, paradoxically, the sole way to render their wish complied with was by categorically refusing to renounce the eradication of the monopoly the Church exercised over the political sphere. Moreover, the Tory party was also caught into the swirling vortex of decline, while the Whigs seized the reins of the government.

Events here adumbrated attest quite audibly to the turbulent and far-reaching metamorphoses taking place within the very roots of political life in England. Because a substantial portion of the Church's contingency proved amenable to the shifting societal paradigms, in the days when the future appeared murky, many in the Church called for the reconciliation of apparently opposing 
beliefs. Newman and those with whom he shared his beliefs, on the other hand, poised themselves adamantly against - from their point of view - a heavy swell of liberalism. ${ }^{1}$

\section{Newman's Mediterranean Journey and the Birth of the Oxford Movement}

Newman's vision of the method that would ensure adequate means of protection for the Church he believed in purified itself when he was abroad. On December 8, 1832, he and his companion Froude, aboard the Hermes, a small passenger boat, sailed from the port of Falmouth to begin their life-altering Mediterranean cruise. The journey's first segment was blessed with no significant exposure to the inclemencies of the elements, allowing them to segue from one place of respite to another in the relative serenity of the sea. The sun-clad margins of Portugal enticed them into the gruesome clutches of cholera infestation ravaging in Gibraltar. Having been quarantined on their ship, and permitted only a short spell on the land during the day, they rather rapidly resumed their journey into the vast blue pastures of the Mediterranean. Merely grazing the plague-infested coasts of Algiers, they for a very hasty interval anchored in Malta, wherefrom they cruised to Corfu, only to set sail back to Malta again, where they replenished their stocks, and via Sicily finally reached Rome on March 2, 1833.

Before Newman and Froude undertook the journey, Hugh James Rose, the founder of the British Magazine, had encouraged both of them, and their friends Isaac Williams, Robert Wilberforce, and John Keble, to contribute their verse to the magazine. They heartily agreed. Their contributions would later constitute a collection of poetry that would go by the name of Lyra Apostolica (1836). Under the impress of the agreement with Rose, Newman, for the greater part of the odyssey, diligently penned all the emotions that the surrounding sea charged with the grandeur of its vastness produced in him. Particularly plentiful did prove the ancient ruins of the Mediterranean world which harkened back to the time of the Phoenicians, Jonah, St. Paul, and St. Athanasius. In one of the letters Newman sent his mother, the inebriation brought about by the effulgent motivity of Biblical myths ensconced in these parts of the world shines forth profusely in his prose:

What has inspired me with all sort of strange reflections these two days is the thought that I am on the Mediterranean - for how much is implied in that one circumstance. Consider how the Mediterranean has been in one sense the seat of the most celebrated Empires and events ... Here Jonah was in the storm - here St. Paul was shipwrecked - here the great Athanasius voyaged to Rome and to Constantinople. (Newman 1891, 303)

Months and, in particular instances, even years later when Newman found himself brooding back on the Mediterranean adventure, the nuances of these bountiful descriptions failed to elude his perceptive mind. As a result of such powerful cognitive reach, Newman was able to turn these associative moments into some of the most cherished English poems of that period. A non-small number of poems, however, were composed during the journey, among which "Athanasius (XCIV)" heralded the birth of a theme that would later come to pervade his writings in the form of the return to the authority of antiquity, whose most delineative emblem of Christian beneficence par excellence, in the eyes of Newman, was to be encountered in the symbolism of Athanasius the Great, who was exiled by Constantine the Great. Newman immediately diagnosed the precedent. He saw the

Newman defined liberalism in Apologia as "the mistake of subjecting to human judgement those revealed doctrines which are in their nature beyond and independent of it" $(1968,218)$. 
configuration of the modern-day persecution of the Churchmen in what he deemed the arbitrary dicta of the State in the exile of Athanasius. In other words, as Herring points out, Athanasius was "something of the Romantic hero ... for Newman, just as for Froude it was Thomas Becket ... who appealed to his particular imagination" $(2002,34)$. It was, therefore, either silence which signified consent or doctrinal independence with the possibility of spiritual if not physical exile:

When shall our northern Church her champion see,

Raised by high heaven's decree,

To shield the Ancient Truth at his own harm?...

Like he who stayed the arm

Of tyrannous power, and learning's sophist-tone,

Keen-vision Seer, alone. $(1849,123)^{2}$

Enamoured with the soaring ruins of Rome, where "pain and pleasure go together" (Newman 1891, 360), the travellers designed a plan to make it a separate travel back home. Froude went straight to Marseille by sea, while Newman, overtaken by the unbridled craving to bathe his eyes one last time with the clear waters of Sicily, opted for a more taxing campaign. From Rome he walked to Naples, where he sojourned for several days. In the meantime, he climbed Vesuvius and without undue restlessness awaited the comradely breath of the wind so that the vessel could put out to sea. As the wind on April 2 proved favourable, he boarded a vessel for Messina, and upon its docking proceeded in the same fashion, partly by land and partly by sea, to Catania, where first the symptoms of typhoid fever started to develop. The illness, which made a serious attempt at his life, Newman interpreted as a form of castigation for his "willfulness in going to Sicily by [himself]" (Newman 1891, 413). Ian Ker, one of Newman's best-known biographers, cites two reasons for Newman's return to Sicily: "First, to see its antiquities, which he had failed to do, and second, to see the countryside" $(2009,79)$.

Upon Newman's continuing convalescence, a decision was made allowing him to leave for Palermo. In this city of Saint Rosalia, an orange Marseille-bound boat awaited him, and the final, yet the most momentous part of this spiritually-oriented Mediterranean travel was to unfold. On June 16, the boat was making its slow progress through the placid Straits of Bonifacio, which afforded Newman an excursion into a reverie of his remarkable escape. Along with the august architectonics and marine terrains, the illness had also bequeathed upon the traveller's keen senses potent impulses which converged into his whirling yen for more life, highly reminiscent of the Falstaffian exclamatory brio of - give me life. If honour truly comes unsearched for, it must follow that Newman's fortunes, enveloped in the shifting poles of the precipitous horizons, bestowed on him the resolve to toil and in toiling, sans vain hopes for immediate self-gratification, meet his

In the letter Newman sent his mother on December 19, 1832, the third verse of the poem reads: "To shield the ancient faith at his own harm?" (Newman 1891, 303) It draws on the idea that "faith is the substance of things hoped for, the evidence of things not seen" (Heb. 11:1, AV). It could be argued then that one must be predisposed to receive the Truth by first believing in the possibility of its omniscient existence. Newman's substitution of truth for faith in the later version of the poem might be one of the earliest indicators of his theological vacillations concerning the interplay of Faith and Truth. Newman endeavoured to solidify the primacy of Truth, provided by God and received through the teachings of the Church, against what he regarded as the pliancy of the Protestant doctrine of Justification by Faith, where the evidence of things not seen in Faith reigns supremely. 
destined verdict. Thus pondering on the upsurge of joy for renewed-life, a desire to return home again, back to the Giant Albion, where work abounded and grew in piles, he composed his most memorable poem, "Lead, Kindly Light": 3

Lead, kindly Light, amid th'encircling gloom,

Lead thou me on!

The night is dark, and I am far from home -

Lead thou me on!

Keep thou my feet; I do not ask to see

The distant scene, - one step enough for me.

I was not ever thus, nor pray'd that thou

Shouldst lead me on.

I loved to choose and see my path; but now,

Lead thou me on!

I loved the garish day, and, spite of fears,

Pride ruled my will; remember not past years.

So long thy pow'r hath blest me, sure it still

Will lead me on

O'er moor and fen, o'er crag and torrent, till

The night is gone;

And with the morn those angel faces smile

Which I have loved long since, and lost awhile! (Newman 1886, 99-100)

Before an adequate elucidation of Newman's literary accomplishments can take place, we are obligated to relate the events that transpired after Newman had, following his safe arrival to Marseille and the ensuing travel up north, finally reached the sands of his homeland. Upon return he learned that "a movement had commenced, in opposition to the specific danger which at that time was threatening the religion of the nation and its Church" (1968, 42). He joined William Palmer, John Keble, Froude, who had long before returned to Oxford, and other friends, in devising a method to propel the Movement towards its auspicious inauguration. Newman held his

3 The poem later came to be known as "The Pillar of the Cloud" and is now one of the most treasured of Anglican hymns. 
ground firmly and insisted that the group circumnavigate any outside exertions seeking to mould the Tractarian initiative into a committee-like institution. Should the Movement prove susceptible to any such form resembling standardized constitution, Newman reasoned, it would ineluctably pursue the pathways of political confederacies, which could potentially cause stern inhibitions to their progress. The key Tractarian ideas expounded upon mainly in the Tracts, but also in the sermons, and other literary outlets, primarily illumined the significance of the concept of Apostolic Succession, while their emphasis in an analogous fashion fell on the need to revive a plethora of disremembered liturgical rituals, and in individual instances even argued for practice of voluntary confessions. The pronounced calls for the rearrangements of church interiors and revitalization of the old liturgical rituals smacked of Ritualism. It must, however, be re-asserted that the Tractarians were predominantly, as Michael H. Bright affirms, "uninterested in the form of worship", and in principle concurs with those who judged Tractarian proclivity to Ritualism as "an aesthetic reaction against the slovenly and irreverent habits of worship" $(1979,398)$.

We have neither identified all of the Tractarian ideas nor afforded them a complete and unobjectionable breadth of comment. This is due to the different objectives of our discussion. The main ideas, however, we have specified, for they press us nearer to a richer comprehension of the Movement's central concept defined by Newman as the Via Media ("the middle path"). The Via Media concerns the Anglican privilege of being positioned between both Protestantism and Roman Catholicism. In Tract 38, Newman writes that the "the glory of the English Church is, that it has taken the via media ... It lies between the (so called) Reformers and the Romanists" $(1834,365)$. In the very same Tract, Newman voices scathing criticism against the Roman Catholicism to which he would, little more than a decade later, convert. In 1834, he continued to exhibit a vigorous aversion to "popery", and following the lead of the Thirty-Nine Articles of Religion - whose religious veracity, by the bye, he would, in Tract 90, published and written four years prior to his conversion (1841), expose to public inquiry by reading them in a Catholic rather than in a Protestant vein - he declares Transubstantiation "profane and impious", calls indulgences "a monstrous invention", and even pronounces a celebration of "divine service in an unknown tongue a great corruption" and confession "a dangerous practice" (Newman 1834, 371). With the passage of several years, Newman's dislike of Roman Catholicism gradually waned - concomitantly to the inflating antipathy he felt towards Protestantism - but he still felt unprepared to accept the doctrine of Transubstantiation. ${ }^{4}$ The scepticism towards Roman Catholicism was mirrored in the Tractarian inability to avoid giving conflicting interpretations of the Eucharist. The smaller segment of the Movement defended the reformed perception of the Eucharist, whereas the other segment, intellectually more formidable, almost unanimously expressed their discontent "against the reformed theology of the Eucharist" (Herring 2002, 38). It took them more than a decade, and Newman had by that time already left their ranks, to settle their questions by seeing in the Eucharist sacramental and "real and not merely symbolic" Presence of Christ in the bread and wine, regardless of "the worthiness of celebrant and receiver" (Herring 2002, 39).

\section{The Devotional Poetry of John Henry Newman}

Can a marriage between one's entangling streams of divino furore, a numinous inspiration - furor poeticus - as Curtius calls it (2013, 474-75), and one's ordinance of ecclesiological beliefs be sustained? Can such a coupling be forged in the first place? What is the significance of furor in poetic vocation? John Henry Newman reached the dawning stages of his creative maturity at the

Transubstantiation is the teaching that the bread and wine during the Mass undergo a transformation into the Holy unity of the flesh and blood (in the form of the Real Presence) of Christ upon the altar. 
time when Britain's most fruitful post-Elizabethan epoch was in a tumultuous decline. Newman was exposed to the novels of Walter Scott, the philosophical writings of Samuel Taylor Coleridge - whom he called "a very original thinker", while decrying his speculations "often heathen rather than Christian" $(1968,84)$ - and both Southey and Wordsworth. His poetic judgements, however, must be analyzed against the backdrop of his religious beliefs, some of which have already been presented. At the tender age of 15, under the over-powering influence of Rev. Walter Mayers, Newman underwent a conversion to Evangelicalism; more precisely, his wandering heart was tutored by the literature "of the school of Calvin"(Newman 1968,16), a guardian in Evangelical Calvinism. Smitten with the doctrines of the total Depravity of Soul and Predestination, Newman, especially under the sway of the latter doctrine, in A Collection of Scripture Passages Setting Forth in Due Order Of Succession the Doctrines of Christianity (1821), which radiates from a steadfast loyalty to the Justification by Faith doctrine, fiercely disparages "baptismal regeneration" (Sheridan 2009, 99). In Apologia, mired in retrospective ruefulness, Newman writes: "I only thought of the mercy of myself" (Newman 1968, 16). In the years to come, he rejected Calvinist tenets and took large steps towards the Visible Church, espousing the credo of the sacramental system, thereby purporting that the "the material world is not just a sign ... it is the instrument" (Sheridan 2009, 102), which, portrayed supernaturally, renders our establishing contact with the world possible.

Having been away on the Mediterranean crusade for a lengthy period of time, ${ }^{5}$ despite its many edifying facets and the fact that he had voluntarily protracted his travel by revisiting Sicily, Newman felt terribly homesick. The news on the theological and political realignments at home reached him through correspondence, invariably dampening his moods. So far removed from England he could not help, yet his homeland was in his "thoughts solely" $(1968,39)$, for he felt the Church was vulnerable. Distancing himself in totality from the youthful vigour of Calvinist reasoning, his meandering ruminations, with each passing year, slanted him in nearer to the pillars of the Roman Catholic Church, until finally, under a charge of doubts with respect to the Catholicity of the schismatic Anglican Church, he became a Roman Catholic.

This overview of Newman's religious background may at first sight seem superfluous, but it will serve faithfully to our purpose of establishing the merits of Newman's verse writing. A proper understanding of Newman's devotional background will aid us in determining the level of oneness that Newman's devotional verse achieved or failed to achieve, for not much intellectual leeway has ever been granted pure poetic frenzy in contemplating devotional practices. In the penumbra of Romanticism, which conceived a deluge of intellectual earthquakes - one such deluge coming in the form of Shelley's The Necessity of Atheism, which earned him an immediate expulsion from Oxford University - Newman formulated a contradistinctive theory of poetry. In his essay Poetry, with Reference to Aristotle's Poetics, in a very axiomatic tone, he writes quite vocally: (1) "It is the charm of the descriptive poetry of a religious mind, that nature is viewed in a moral connexion; it is overpowered by a rush of emotions" $(1891,13)$ and $(2)$ "the poetry of a vicious mind will be inconsistent and debased" $(1891,23)$.

Both premises correspond to the Tractarian aesthetics of literary creation, which G.B. Tennyson defines as the "outpouring of intense religious feeling" (1990, 33), and he identifies them as the Doctrine of Analogy and the Doctrine of Reserve. Even after the conversion, Newman's religious allegiance to the dyad of the Tractarian aesthetics never truly shifted. Analogy incessantly

At the time of the trip, however, he still was not present in the full realization of the significance of the sacrament: "I began to visit the Churches, and they calmed my impatience, though I did not attend any services. I knew nothing of the Presence of the Blessed Sacrament there" (Newman 1968, 40). 
refurbishes a symbolic union between the haecceitas of material and immaterial realities; it is a prime representation of Divine forces governing the world. Reserve, on the other hand, was designed to disinvite any lurking paroxysms of Evangelical abandon from the domain of selfless devotion. Analogy is, therefore, the "subject matter" and Reserve controls "the style" (Plotkin 1994, 458) of the Tractarian aesthetics.

For Newman poetry was inferior to the doctrines of the Church. We must, however, amend Newman's rather precarious subjection of poetry to religion by introducing the concept of devotional poetry. The hymnal overtones of Newman's poetry render the aesthetic value of his poetry highly questionable. It is devoid of the Reserve his homiletic lectures abound in. The latter, owing to their signal voice of analytic detachment, are held in much higher regard even among secular circles than his poetry is. The sacrificial nature of devotional poetry builds a unidirectional point of comparison, from which point something which is likened to another thing, in matters religious, without fail treads a linear path of an entity, in its physical or noumenal constitution, inferior to the entity being upheld as a primal standard of that comparison. The relationship never alters; it is mimetic, with its goal remaining unchanged. It is always one kindly Light, which makes life conceivable, the journey being roused out of its dormancy merely in the light of the kindly light. Doubt in the privacy of one's thoughts is hardly a permissible criterion of one's relationship with the external world; any form of public discourse, even a brief appearance on the universal stage of life, must not ignore the blinding light of the Truth.

Samuel Johnson had his, not very private, doubts regarding devotional poetry, and in The Lives of the Poets writes:

Sacred History has been always read with submissive reverence, and an imagination overawed and controlled. We have been accustomed to acquiesce in the nakedness and simplicity of the authentick narrative, and to repose on its veracity with such humble confidence, as suppresses curiosity. We go with the historian as he goes, and stop with him when he stops. All amplification is frivolous and vain; all addition to that which is already sufficient for the purposes of religion, seems not only useless, but in some degree profane. $(2009,41)$

For Johnson an imagination over-awed and controlled is a cardinal sin committed against the ethos of poetic creativity as he understood it. ${ }^{6}$ Such constricting landscaping can be counterbalanced in more wit-inspired inventions. John Donne, a metaphysical and partly devotional poet, managed the task. Does Newman's poetry possess Donne's wit? The answer, naturally, hinges upon one's definition of wit. In Donne's case it surfaces as coalescence of extreme acumen and humour. With Newman humour did not fit his overly glacial clerical habiliments, while the acumen is present, but it often does not show. Newman's irregularly beautiful style seldom vitally reinvigorates the tired and clichéd sinews of language. The reader's ambition to comb the rhyme-entwined verses for ideas depicting "an original vision of the cosmos" thus often hangs unsated (Taylor 1992, 85). One cannot rid oneself of the sensation that Samuel Johnson is but right in his verdict that most devotional verse writing occupies itself with "writing in rhyme, instead of writing poetry" $(2009,15)$.

\subsection{John Henry Newman and Romanticism}

There has been many an attempt to draw parallels between Tractarian and Romantic poetry. A

Over-awed in a sense of being in awe and thus controlled by some religious agency. Johnson, however, was equally wary of the limitless possibilities of Imagination, and was striving to balance the two opposite poles. 
fundamental difference, however, exists between the two groups. One can produce a number of similarities also, primarily the rejection of the Enlightenment and vulgar rationalism, and a consequent call for more intuition-stimulated ratiocination. But, adhering to the principle of "true holiness" (Herring 2002, 42), the Tractarians vigorously opposed the Romantics' inordinate reliance on the self. They both shared a deep-seated affinity to medievalism and the ruined and haunted venues of the old churchyards. Not rarely does the theme from Oliver Goldsmith's "The Deserted Village", Thomas Gray's "Elegy Written on a Country Churchyard", or Wordsworth's The Prelude and "The Ruined Cottage", reappear in Isaac Williams' search for the splendours of the past.'

The kinship of ideas melts into the background and gets disrupted when the Protestant sola fide doctrine is introduced. Newman never returned to re-consider his rebuttal of the doctrine of justification by faith alone. Sheridan Gilley alludes that Newman abandoned the doctrine on the grounds of its "neglect of hope, love, good works, sacraments, holiness and righteousness" (2009, 8). This mental transmutation would imprint an indelible mark on his subsequent literary ventures. Let us for a moment dwell at this point to make clearer our distinction. In an introductory essay to The Visionary Company, a collection of his essays on English Romantic Poetry, Harold Bloom deploys a compelling argument on the relationship between Protestantism, Roman-Catholicism, Anglicanism, and Anglo-Catholicism, and their influence on the British literary traditions, particularly on Romanticism. Notwithstanding their disparities, Bloom demarcates, as a single formation, the last three religious groups from Protestantism. Bloom contends that the English Romantic poets - although many of them were openly atheist or at least not religiously-swayed built a lofty tower of "a kind of religious poetry" under the spell of Protestantism, or, as Bloom states, "displaced Protestantism" (1971, xvii). The Tractarians advised against the individualistic nature of Romantic intuition of the self. Anti-Romanticism akin to that of the Tractarians' was given added stimulus by the New Critics. T.S. Eliot's inability to separate ideas from poetry made it impossible for him to enjoy Shelley's poetic work, which he considered childish and churlish, or any other work, for that matter, by "Puritans, or Protestant individualists" who - by recanting the visual opulence of the Church and choosing heart as the only fair emanation of the "creative Word of God" (Bloom 1971, xviii) - fled away from the Church "to formulate personal religions in their poetry" (1971, xviii). The New Critics' predilections resided with Donne, Herbert, Pope, Hopkins, etc. (1971), ${ }^{8}$ yet none of the aforementioned poets deserves to be appraised on the basis of their personal convictions alone, for just like the Romantics they all had sublime moments, despite the fact that they all imposed upon themselves sometimes extreme apotropaic gestures to repress the florescence of the self.

I slowly wander'd through the site
Of crumbling walls, half-falling tower,
Mullions and arch, which darkly lower
And o'er the intruder seem to frown,
Putting on size beyond their own,
Like giants in enchanted tale,
As dimly seen through misty veil...
Such legends, if they be not true,
Speak what our nature here divines
'Mid holy sepulchres and shrines!
Such thoughts in me a place have found
'Mid contemplations more profound,
And seem to mingle with my themes
More true than life such holy dreams;--
I deem in them more truth to lie
Than all man's cold philosophy. (Williams 1844, 236-37)
The New Critics, contrary to Bloom's assertion, expressed ambivalent attitudes toward the poetry of Gerard Manley Hopkins.
T.S. Eliot's appraisal of Hopkins' verse rarely exceeded the lower strata of lukewarmness.


Newman took this repression of the daimon-within a step further. We have already established that Newman expelled the elements of viciousness and immorality from the province of poetry, with the expressions of the pure and the God-loving being the only permissible forms of poetic narration. Strong poetry, however, is neither an alembic nor a purveyor of unequivocal emotions or unblemished reflections solely; it is more than anything a quest for knowledge. Newman felt no need for such a quest, for a rigid system of mental fixation upon the One omniscient Light, the source of eternal selfsameness, can hardly be called a quest for knowledge. A quest demands a wrought-in doubt, the state of being lost.

Presented here are the first and fourth quatrains of Newman's famous hymn-poem "Praise to the Holiest in the Height" (from The Dream of Gerontius):

I.

Praise to the Holiest in the height,

And in the depth be praise;

In all His words most wonderful;

Most sure in all His ways!

IV.

And that a higher gift than grace

Should flesh and blood refine,

God's presence and His very Self,

And Essence all-divine. (Newman 1903, 60-61)

The speaker of the poem delivers, in an interminable stream of prayer-like parlance, a eulogy to the ever-vernal incarnate presence of Christ. The poem displays no tenebrous moments of the speaker's faith. Faith in "Praise to the Holiest in the Height" is a corollary of a heteronymous dogma-infused certitude of salvation. Thus bereft of doubt, it cannot proclaim faith; it merely regurgitates the precepts of its religious dogma. It must, yet again, be emphasized that Newman's personal religious beliefs are of no intrinsic relevance to our task, but, given that they were brought over into the realm of poetry by the poet himself, they surely gain pertinence. There - in the orthodoxy of their depiction - they impeded his creative fervour and caused him to write a certain type of poetry. Gerard Manley Hopkins, for instance, was a Jesuit priest and a great admirer of Newman's, but Hopkins the poet, judged purely on his artistic achievements, by far overshadows Newman the poet. Hopkins is an illustrative example of a poet whose works are permeated with the orthodox views of Catholicity, but his doubts - quite pronounced and pregnant with existential anguish (particularly those expressed in the Terrible Sonnets), while also closely intertwined with orthodoxy - let his poetry speak in its own voice, and in this fashion resist the urge to preach.

Bloom states that the English religious dissenters were more insistent on "intellectual and spiritual independence", where nothing ever came between "a man and his god" (1971, xviii). Newman's inability to dissociate himself in his verse - not that he tried to act otherwise - from an imitative sound of devotional practices precluded him from achieving levels of creative independence necessary 
to challenge effectively the Platonic demotion of poetry to the territory of mimetic responsibilities. In his $A$ Defence of Poetry, Shelley refutes Plato's heavy-handed imputations against poetry:

[T] he before unapprehended relations of things and perpetuates their apprehension, until the words which represent them, become, through time, signs for portions or classes of thoughts instead of pictures of integral thoughts; and then if no new poets should arise to create afresh the associations which have been thus disorganized, language will be dead to all the nobler purposes of human intercourse. $(2003,676)$

Innovation is the sine qua non of the Romantic daimon. The daimon of self-reliance faces a confrontation with the antitheses of the past in the figures of precursors. Agon begets faith, for the latter always materializes in the teeth of its antagonist, and its antipodal formation manifests itself in despair. In Newman's poetry, however, the blissful kinship of a son, so to speak, and his father is at no time compromised. The cog dares not reverse the wheel's smooth circular motion. While in everyday situations built-up tension undoes the unity of the phenomenal world, in poetry a poverty of such a tension provokes the opposite reaction. Lucretius, a master of Clinamen, describes the reclining motion of atoms as being constitutive of the wholeness and completeness of the Universe. If imagination for the neo-classical literati represented perilous and passive shadows of the unknown, the Romantics transfigured the shadows of the unknown into the burning coals of creative impulse.

Blake's Albion could not come to terms with love and piety of "a soft repose, / Inward complacency of soul, a self-annihilation" $(2008,182)$.

In his ambitious and longest poem, The Dream of Gerontius, Newman relates the story of a fastexpiring man and the passing of his soul through purgatory. The poem's strongest moments are reserved for the dying man's uncertainty with which he must confront the oncoming darkness:

I can no more; for now it comes again,

That sense of ruin, which is worse than pain,

That masterful negation and collapse

Of all that makes me man; as though I bent

Over the dizzy brink

Of some sheer infinite descent. (Newman 1903, 31)

This fear is soon superseded by a chorus of Angels singing a dirge for poor Gerontius' salvation, and is, upon Gerontius' departure from physical existence, closely followed by an assemblage of demons calling a saint, in a surprisingly witty moment:

\footnotetext{
While atoms move by their own weight straight down

Through the empty voice, at quite uncertain times

And uncertain places they swerve slightly from their course.

You might call it no more than a mere change of motion.

If this did not occur, then all of them

Would fall like drops of rain down through the void.

There would be no collisions, no impacts

Of atoms upon atom, so that nature

Would never have created anything. (Lucretius 2008, 42)
} 

A bundle of bones,
Which fools adore
$\mathrm{Ha}$ ! Ha!
When life is o'er;
Which rattle and stink
E'en in the flesh. (Newman 1903, 46)

Still the poem remains a lodestone for doctrinal readings. The soul of Gerontius suspended in the darkness of perplexity lingers "sight-bereft" (Newman 1903, 48), impotently awaiting a kind of enlivening baptismal regeneration. The soul absolved, the demonic chants seem more like a self-reverberating echo, an unadulterated prattle which cannot stir the soul to muse and possibly reweigh its thoughts. The Lord's decree has ordained that the wandering soul be roused "on the morrow" (Newman 1903, 66) from its slumber and delivered to his bosom.

Simon Critchley defines faith as that which "announces itself in a situation of crisis where a decisive intervention is called for" (2012, 161-62). Poetic faith does not strive to bargain out a salvation. It declines servitude, and if "in the beginning was the Word, and the Word was with God, and the Word was God" (John 1:1, AV), then, in Heidegger's words, "language itself is-language and nothing else" $(2001,188)$. Being well-aware of the tautological nature of his proposition, Heidegger, several lines later, affirms that tautology leads no-where, and here lies the biggest difference between Newman and the Romantic tradition of poetry. This no-where is further expounded upon by Heidegger, who affirmed that "we do not want to get anywhere. We would like only, for once, to get to just where we are" (Heidegger 2001, 188). The being of no-where and thus of every-where gives rise to the sensation of anguish which, in turn, transfers one into the "closest neighbourhood of [one's] being" (2001, 187). The Romantic poets do not step outside language; they are in-side and out-side, not anywhere but nowhere and everywhere at once. Newman would argue that the innate yet external authority or agent of any language is God, but language speaks itself, and lets itself be spoken. Language, impervious to all command, alone enables the command to be spoken as such, so that anguish in this sense is "the only proof (endeigma) of the calling" (Critchley 2012, 170), of poetic calling. Poetic language is not in the service of theology; it is rather that the latter can - if only it would unburden itself of the compulsion to sermonize through the agency of poetry - serve the voice of the Muse. ${ }^{10}$

\subsection{John Henry Newman and Samuel Taylor Coleridge}

Revering both Joseph Addison and Alexander Pope, Newman's acclamatory propensities rested largely with the Neoclassical artists. But for all this, Romanticism, particularly Samuel Taylor Coleridge, was never wholly displaced from the purview of his devotional posture. Despite calling him a heretic, Newman deemed a number of Coleridge' late works valuable, but with respect to his early theories on the nature of poetic creativity, Newman proved less eager to grant them any copious amount of leeway.

In Biographia Literaria, Coleridge writes extensively on the subject of Imagination in search of the lost poetic voice:

10 When Hopkins in 1868 burned his early poems, he later referred to the act of incineration as the slaughter of the innocents. 
The primary imagination I hold to be the living power and prime agent of all human perception, and as a repetition in the finite of the eternal act of creation of the infinite I AM. The secondary I consider as an echo of the former, coexisting with the conscious will, yet still identical with the primary in the kind of its agency, and differing only in degree, and in the mode of its operation. $(2008,313)$

The primary Imagination is the fundamental attribute of that which is, of the intangible reality, in the unceasing and active process of becoming. The secondary type of Imagination is posterior to the primary one; it rationalizes its existence by the attempts to re-create that first throb, prima causa, of innovation, which relegates it to a lower-mimetic-quality. The first form "shapes truth", the second one "merely takes it, through nature, from the Shaping Spirit of its creator" (Bloom 1971, 212). The secondary Imagination always confronts a peril of falling into the abyss of Fancy (of torpid fancifulness) which is nothing else "than a mode of memory emancipated from the order of time and space" (Coleridge 2008, 313). At the intersection of the categories of the secondary Imagination and Fancy, Coleridge the disillusioned poet of the late period and Newman cross their paths. Newman recognizes Imagination as an indispensible mover controlling the development and organization of the human mind; but, favouring its passive rather than active mien, he never relented in his admonishments against the potential detriments of undisciplined imagination. His was a fear of witnessing a total usurpation of the fortresses of moral and temperate human intuition.

Coleridge's early poems are awash with the premonitions of the oncoming demise of his own poetic genius. Two stages of Coleridge's poetic genesis can be identified. The earlier period (1797-1811) was that of his highest creative splendour, while the later one (1815-1834) saw a downturn in the spiral of visionary sagacity. In the mature stage, Coleridge settled for nature with a human face, abandoning, in a course of time, ${ }^{11}$ the towering imaginative aspirations of his youthful poetic days. His mind then traced applicable designs for Imagination. In limbo amid the imaginative and the fanciful, he wrote Biographia Literaria (1815-1817). There he furnishes the reader with perceptive insight into the workings of Imagination, and then also, quite ambivalently, veers off into the pragmatic analysis of "the scheme of Christianity as taught in the liturgy and homilies of our Church, though not discoverable by human reason" (Coleridge 2008, 482). Herein lies the principal reason for Newman's preference for Coleridge the speculative thinker to Coleridge the poet; the preference for Coleridge, who, as Herbert L. Stewart writes, channelled his efforts towards the promotion of the "organized and visible community which had been founded by Christ" (1918, 30-31).

The teeming brain of the Romantic mind obtained no mercy either from Newman or other Tractarians. Poetry, as they by and large understood it, was a tool of travail in the service of the Divine reason, while the object of its discourse must never diversify its role. Newman would not and could not read or write poems in the seclusion of his thoughts far removed from the doctrines he served. He looked upon the shores of Romanticism from the far-away horizon. Newman's genius as a preacher and master of argumentative discourse is canonical, yet his daimon poeticus slumbered away.

1n 1832, Newman bade the wind blow southerly for the first time, southerly to the Mediterranean. Apparently only the land with such unearthly sceneries and history as to give us Shelley, Byron, and Keats could have inclined Newman to the appreciation of the Poetic Imagination, whose dread-

11 "Work Without Hope" (1825) is filled with pathos regarding the fallen genius of creativity and is one of Coleridge’s strongest late poems. 
inciting provenance can yield knowledge, and need not be regarded as the subject of unseemly decay, wherein Imagination would destitute itself into a mere phantasm. It failed to do so, for in 1845 , when he bade the wind blow southerly again, he went and left his heart there in perpetuum, swearing eternal fidelity to the Holy See.

\section{Conclusion}

John Henry Newman was one of the founders of the Oxford Movement. The members of the Movement envisaged its function as that of a bulwark against the flooding tide of liberalism growing in the Anglican Church. Crucial to Newman's revolt against the displacement of some of the Church's time-honoured traditions was the Mediterranean trip (1832-1833) where his determination grew exponentially to retard the thriving processes that were rendering the Church invisible and that were brought into existence by the secular agencies. His anxiety increased due to the fact that he was far away from home and felt exposed to the unending self-accusations of not being able to help in that grave time of need. The news he kept receiving in the form of letters from his friends bore no glad tidings. Embraced he was, however, by the immense historical heritage of the Mediterranean, and the powerful sway of Biblical symbolism in the scenery of Greece, Malta, Italy, and Sicily whelmed him with great affection for antiquity and the Church Fathers. His reaffirmed beliefs would, upon his returning back home, help define the direction of the Movement in their attempts to restore the Visible Church. In his youth, Newman underwent an Evangelical conversion and espoused the doctrines of Calvinism. The infatuation with Calvinism quickly wore off, and Newman grew fonder of the notion of the Visible Church, which was closely tied to the concept of the Via Media, first developed by Richard Hooker in Laws of Ecclesiastical Polity, and slightly re-modified by Newman. Generally perceived as the middle way between the pillars of Protestantism and Roman Catholicism, under the impetus of Newman and Froude, the Anglican middle way began to favour more and more the Roman rather than the Protestant way.

Although Newman wrote verse for the greater part of his life, it was during the Mediterranean trip and for a short time after that trip that Newman produced some of his best known poems. Incidentally, this was also the time of the decline of Romanticism. Newman's affinity for Romantic poetry flew very low owing to its Imaginative nature. Walter Pater, a secular aesthete from Oxford, defined Romanticism as the "addition of strangeness to beauty" (2010, 258). Strangeness in Newman's poetry was made conspicuous by its absence. In his eyes poetry was an organ of the divine Gospel on the earth. Its vitality must not be utilized to vindicate delusion or dubiety or blasphemy.

Coleridge was the only Romantic whom Newman did not banish from his politeia, and he granted him this privilege on the grounds of his philosophical, theological, and mature poetical writings. His earlier poetry he deemed sacrilegious. Thomas Chatterton was one of the first victims of too bright an Imagination, and Coleridge knew that "music loud and long", the creation of which would build "that dome in air" (Coleridge 1996, 27), could wield its sword quite cruelly upon its host. In the final quatrain of the poem "Fair Words", Newman warns against the insouciance of one's spirit:

Beware! such words may once be said,

Where shame and fear unite;

But, spoken twice, they mark instead

A sin against the light. $(1886,50)$ 
Lingering in the shadows was commensurate with Newman's apperception of sinning against the Light. For this reason, Newman chose not to dwell in the intense shadowlands of Romanticism. He yearned to leave the cave to see the Sun mirrored against the sky. He devoted his life to the service of the Holy Sacraments and the Creator who sanctified them. The epitaph on his grave reads: Ex umbris et imaginibus in veritatem - out of shadows and into truth. He refused to tarry in the shadows for poetry's sake and settled gently for the poetic life of imitation.

\section{References}

Blake, William. 2008. Selected Poetry. Edited by Michael Mason. New York: Oxford University Press.

Bloom, Harold. 1971. "Prometheus Rising: The Backgrounds of Romantic Poetry." In The Visionary Company: A Reading of English Romantic Poetry, xiii-xxv. New York: Cornell University Press.

-. 1971. The Visionary Company: A Reading of English Romantic Poetry. New York: Cornell University Press.

Bright, Michael. H. 1979. "English Literary Romanticism and the Oxford Movement." Journal of the History of Ideas 40 (3): 385-404. Accessed July 26, 2015. http://www.jstor.org/stable/2709244.

Coleridge, Samuel Taylor. 2008. "Biographia Literaria.” In The Major Works, edited by H. J. Jackson, 155-482. New York: Oxford University Press.

—. 1996. Samuel Taylor Coleridge: Everyman's Poetry. Edited by John Beer. London: J.M. Dent.

Critchley, Simon. 2012. The Faith of the Faithless: Experiments in Political Theology. London: Verso books.

Curtius, Robert Ernst. 2013. European Literature and the Latin Middle Ages. New Jersey: Princeton University Press.

Froude, Hurrell Richard. 1839. Remains. Derby: Henry Mozley and Sons.

Gilley, Sheridan. 2009. "Life and Writings". In The Cambridge Companion to John Henry Newman, edited by Ian Ker and Terrence Merrigan, 1-28. New York: Cambridge University Press.

Heidegger, Martin. 2001. “Language.” In Poetry, Language, Thought, edited and translated by Albert Hofstadter, 185-208. New York: Harper Perennial Modern Classics.

Herring, George. 2002. What was the Oxford Movement. London: Continuum.

Johnson, Samuel. 2009. The Lives of the Poets: A selection. Edited by Roger Lonsdale. New York: Oxford University Press.

Joyce, James. 2000. A Portrait of the Artist as a Young Man. London: Penguin Classics.

Ker, Ian. 2009. John Henry Newman. New York: Oxford University Press.

Lucretius. 2008. On the Nature of the Universe. Translated by Ronald Melville. New York: Oxford University Press.

Newman, John Henry. 1968. Apologia Pro Vita Sua. Edited by David J. DeLaura. New York: W.W. Norton \& Company.

—. 1903. The Dream of Gerontius. Bombay, London, and New York: Longmans, Green, and Co.

—. 1886. Hymns. New York: E.P. Dutton \& Company.

—. 1891. Letters and Correspondence of John Henry Newman. Edited by Anne Mozley. London and New York: Longmans, Green, and Co.

—. 1849. Lyra Apostolica. London: Rivingstons.

—. 1891. Poetry, with Reference to Aristotle's Poetics. Edited by Albert S. Cook. Boston: Ginn \& Company. 
—. 1834. Tracts for the Times. London: J.G. \& F. Rivington.

Pater, Walter. 2010. Studies in the History of the Renaissance. Edited by Matthew Beaumont. New York: Oxford University Press.

Plotkin, Cary H. 2013. “Victorian Religious Poetry.” In The Columbia History of British Poetry, edited by Carl Woodring and James S. Shapiro, 452-77. New York: Columbia University Press.

Shelley, Percy Bysshe. 2003. "A Defence of Poetry." In The Major Works, edited by Zachary Leader and Michael O’Neill, 674-701. New York: Oxford University Press.

Sheridan, Thomas L. 2009. “Justification." In The Cambridge Companion to John Henry Newman, edited by Ian Ker and Terrence Merigan, 98-117. New York: Cambridge University Press.

Stewart, Herbert L. 1918. "The Place of Coleridge in English Theology.” The Harvard Theological Review 11

(1): 1-31. Accessed August 1, 2015. http://www.jstor.org/stable/1507390.

Taylor, Charles. 1992. The Ethics of Authenticity. Cambridge: Harvard University Press.

Tennyson, Georg B. 1990. "Removing the Veil: Newman as a Literary Artist.” Renascance 43 (1-2): 29-44.

Williams, Isaac. 1844. The Baptistery or The Way of Eternal Life. Oxford: John Henry Parker; London:

Rivingtons. 